


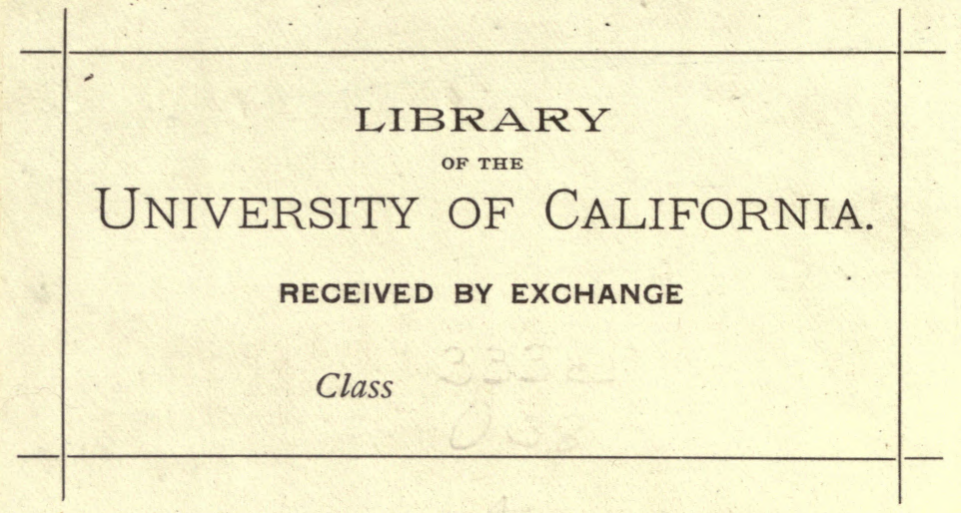







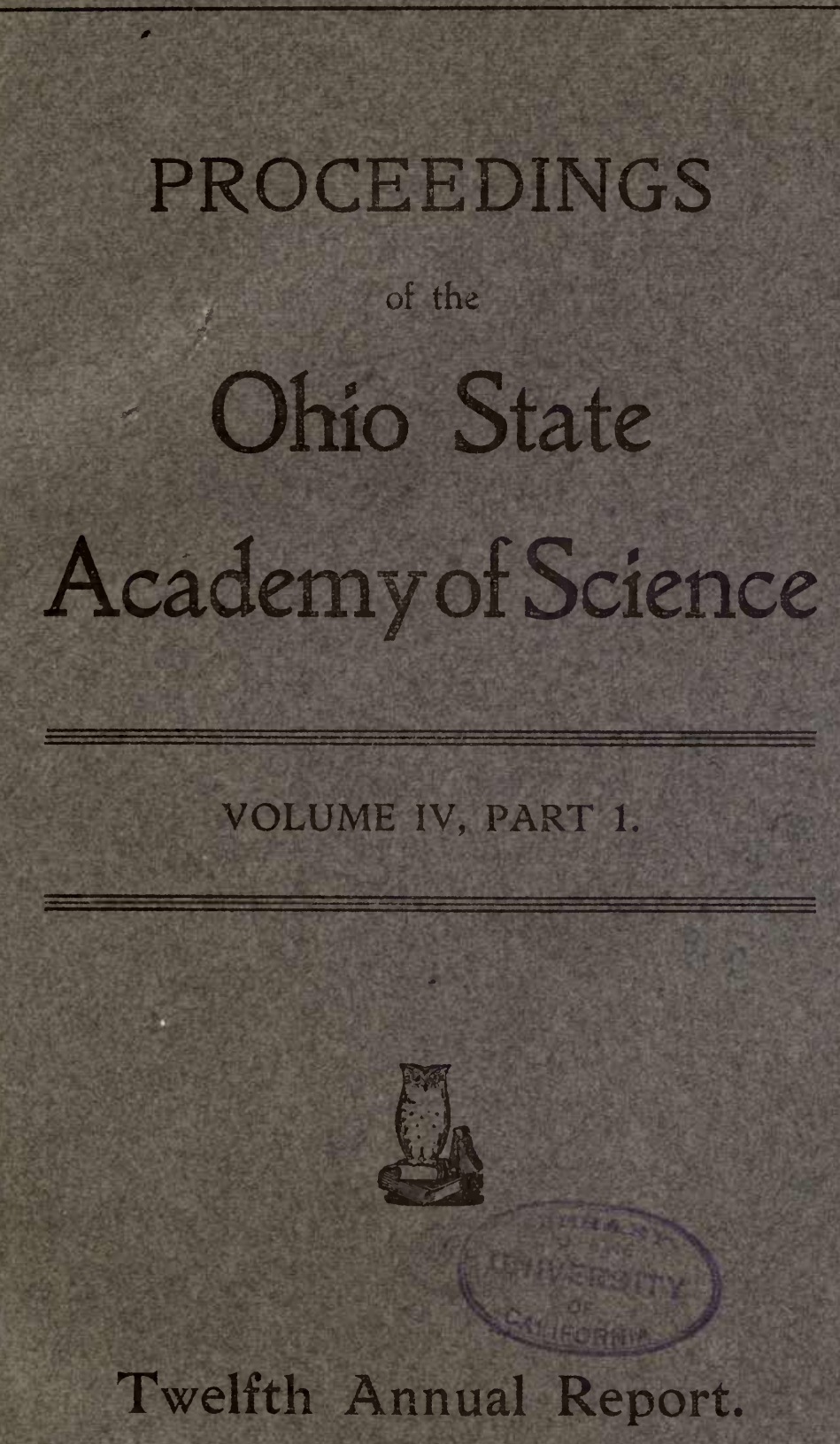




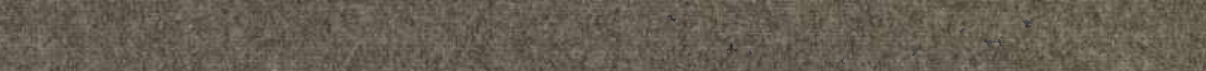

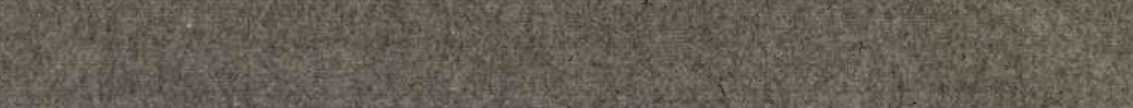
Q7. ate

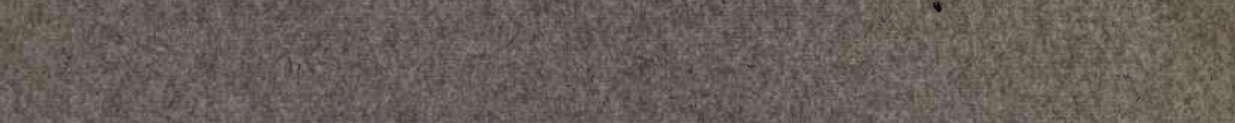

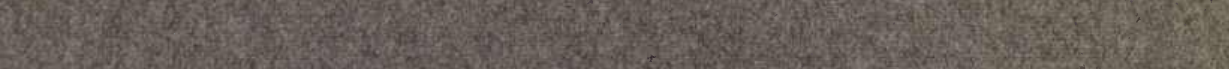

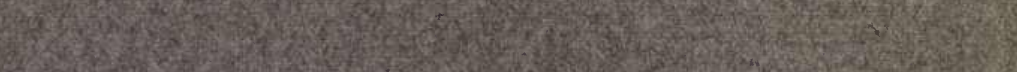

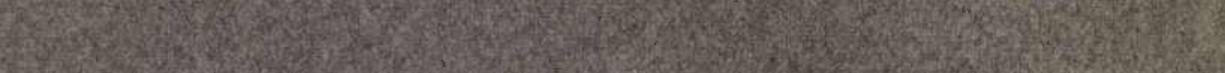

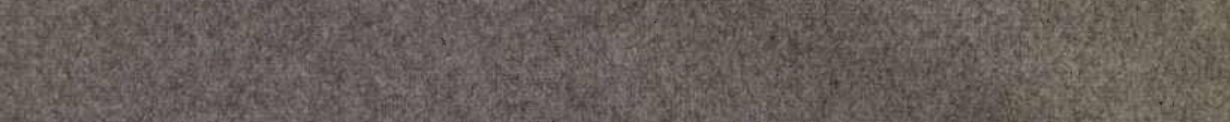

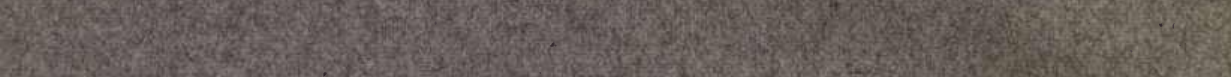
Sc

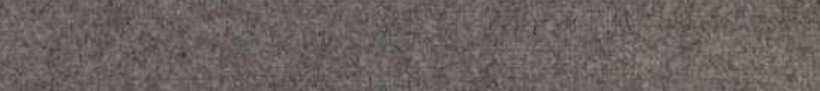
4. 2.

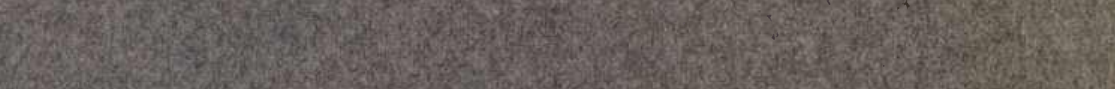

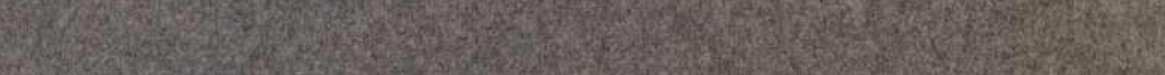

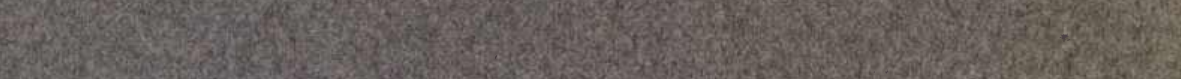

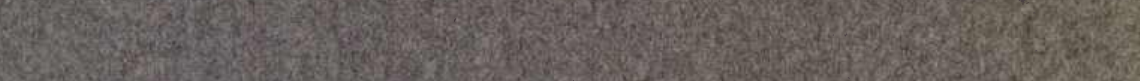
W.

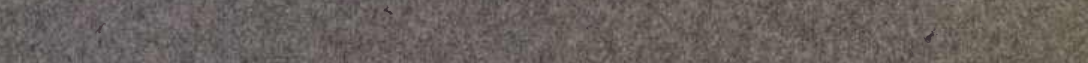
20.

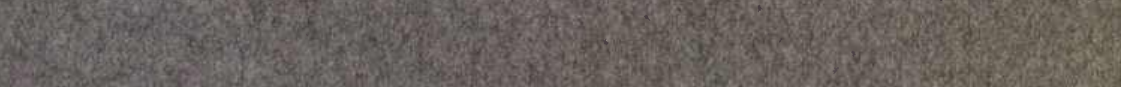

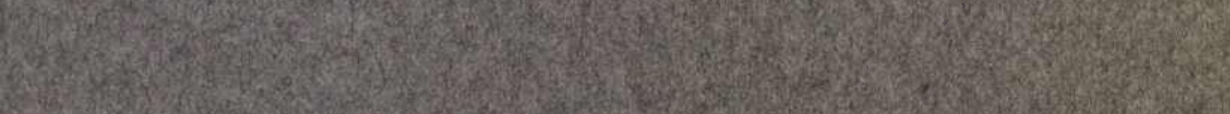
Wisis

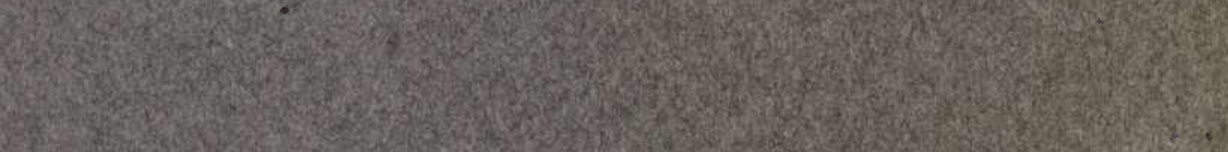

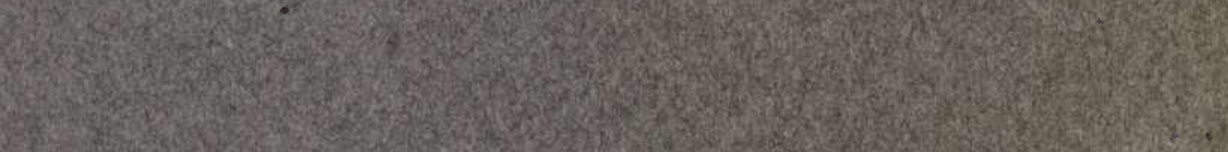
W.

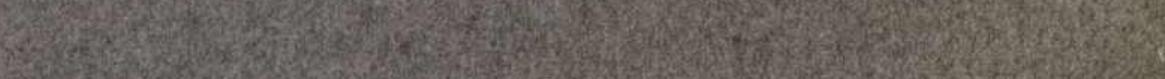

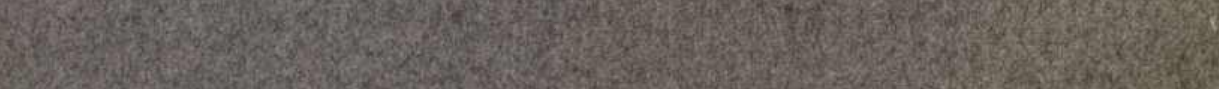

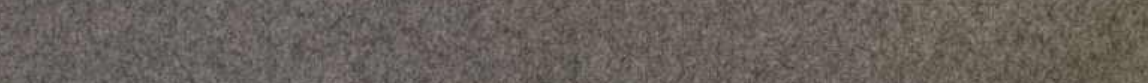

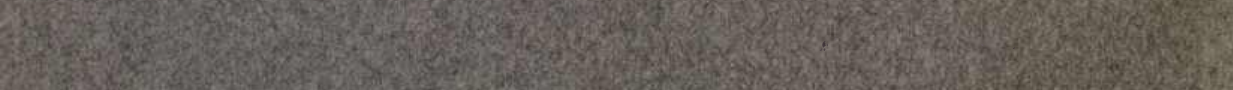

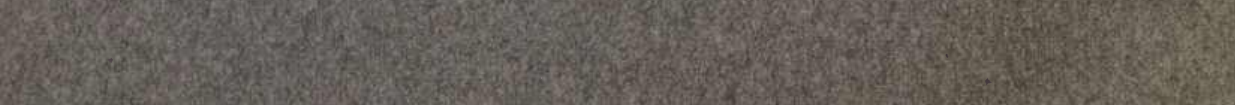

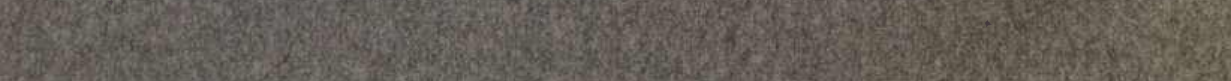
513. H. for 
adults are commonly found in cellars, under boards, near springs, as well as under logs in damp places. When the colder weather of autumn sets in, individuals are frequently found entering sewer pipes where a promise of warmth is given. Several are taken each autumn in the basement of the Biological Hall at O. S. U. This species is generally killed outright by those who believe them to be dangerous. They are harmless.

Very common over the State, in fact one of our most familiar salamanders.

Specimens in U. S. Nat. Mus., recorded by Cope from Columbus and Marietta. In O. S. U. Mus., collected by E. V. Wilcox and the author fromi Columbus.

Amblystoma xiphias Cope. Similar to preceding, but ground color, light yellow. Tail long, exceeding in length that of head and body. Costal grooves twelve. Head small in proportion to body. Lower jaw prominently projecting. Canthus rostralis, distinct.

This is a doubtful species, inasmuch as but one specimen is known. This is in the U. S. N. M., being collected at Columbus, Ohio. The present writer has carefully examined every specimen that has come under his notice and but one showed any approach to Cope's description. (Cope, '89.) 'This had the length of tail equal to that of head and body and a slightly projecting lower jaw, while the ground color was a light yellow. (Morse, 'or, May.) But gradations occur between such a type and the normal form and it is doubtful whether it is a valid species.

Specimen in U. S. Nat. Mus, recorded by Cope from Colunıbus.

Amblystoma jeffersonianum jeffersonianum Green. Body slender and elongated. Head long, width being four times in length to groin. Costal furrows 12. Tail nearly equal to head and body. Ground color brown to black, with a sprinkling of light spots a quarter of an inch or less in diameter. Sometimes no spots are visible. Length 8 inches or under.

This sub-species differs from the following, platineum, by having a wider head, under parts not paler than upper, blotches dirty white, eye smaller.

Specimens in the U.S. Nat. Mus., recorded by Cope from Ripley and Cleveland. In Cin. Soc. Nat. His., collected by C. W. Hohn in Hamilton Co.; in Oberlin College, collected by Lynds Jones in Lorain Co. 
Amblystoma jeffersonianum platineum Cope. Plumbeous, paler below. Width of head less than three times in length to groin. Eye larger. Body-length longer. Costal grooves 12.

The sub-species platineum resembles somewhat individuals of Plethodon glutinosus, but it may be told from that species by its slenderer shape and the absence of parasphenoid teeth.

Little seems to be known of the habits of the sub-species. DeKay gives them as frequenting springy places. (Paulmier, '02, p. 399.) In the State they are not common.

Specimens, in the U.S. Nat. Mus., recorded by Cope from Cleveland. In Oberlin College, collected by Lynds Jones in Lorain County.

${ }^{7}$ Amblystoma microstomum Cope. Costal grooves I4. Color blackish, with a plumbeous tinge, spotted indistinctly sometimes with lighter. Head broad, but small, and fusing with the body without a neck being evident in proportion to body. Lower jaw prominent. Tail not as long as head and body, round, compressed posteriorly. Legs small. Altogether the slenderest species. Length 8 inches.

Occurs in the State in general, but more common in hilly regions. They leave the water after breeding and are to be found under logs and partly buried in damp turf. The small eggs are attached to water weeds in little masses. By June they are ready to leave the water. At times this species leaves its winter quarters while it is yet winter, being taken in February. (Garman, '9r.)

Specimens in the U. S. Nat. Mus., recorded by Cope from Columbus. In the Mus. Cin. Soc. Nat. His., collected by Chas. Dury in Hamilton Co.; in O. S. U. Mus., collected by E. V. Wilcox at Lancaster, and E. E. Masterman at New London.

\section{Family: Plethodontidae.}

Hemidactylum scutatum Tschudi. Above brown, lighter below where there is a sifting of dark blotches. Sometimes plumbeous dorsally, snout light. A marbling in the median dorsal region. Costal grooves $\mathrm{3}$. Length 3 inches. Toes $4-4$.

This species may be distinguished from those of the genus Plethodon by its having only four toes in the hind feet.

It is a rare species for Ohio, but one specimen being thus far recorded. However, Hay ('92) mentions forty being taken at Brookville, Ind., which is within to miles of the Ohio-Ind. line.

Specimens in the U. S, N. Mus., recorded by Cope from Ripley, Ohio; collected by Hoy.

7. I follow Stejneger in discarding the genus Chondrotus Cope. 
Plethodon cinereus cinereus Green. Body slender, plumbeous to ash above; below a pepper-and-salt appearance, turning to uniform light on the mid-ventral line. Inner toes reduced. Length 4 inches. In alcohol the body becomes brownish. Costal grooves I8. Legs small and weak, webbing well developed. Distinguishable from the following by the absence of the dorsal band of red.

At Suga: Grove and elsewhere the writer has repeatedly taken, along with good examples of the following sub-species, specimens that are referable to the sub-species cinereus.

At Worthington, a litter of young was found in which about one-half were provided with the dorsal red band, and the remainder showed no sign of it. For reasons such as these, Jordan ('99) does not recognize the sub-species and the position seems a correct one. It may be said, however, that in the great majority of specimens the red band is evident to a greater or less extent.

Specimens in the U. S. Nat. Mus., recorded by Cope from Ripley. In the O. S. U. Mus., collected by E. V. Wilcox at Sugar Grove, and the author at Columbus; in the Cin. Soc. Nat. His. by Dr. Lindahl at Cincinnati.

Plethodon cinereus erythronotus Green. Same as above, but with a median longitudinal dorsal band of red.

Cope, '89, p. I 35 : "I have been unable to detect any difference in structure, proportions and general character between this supposed species and the foregoing." Again (1. c. I36), "as varieties they are very permanent ones, as I have found all the young of the same brood or set of eggs, whether in the eggs or just escaped from them, uniformly with either dark backs or red ones." From the remarks under the sub-species, cinereus, it will be seen that the present writer does not agree with Cope. Wilcox ('9I) records "numerous specimens of erythronotus" at same date and place and under same circumstances as the preceding. Withal the validity of the sub-species is doubtful.

Dr. Lindahl of the Cin. Soc. N. H., writes: "Common throughout Hamilton Co.; the one colored grey and the chestnut-black varieties often occurring in the same litter, together with intermediate forms with a more or less faint reddish hue along the back."

The commonest of the salamanders in Ohio at the present time. Occurs over the State, being found in numbers almost 
everywhere, but especially in ravines and around rocky streams. They are not aquatic, their eggs being laid under logs, etc., away from water. The adults are to be found in comparatively dry places under rotten wood and stones.

Specimens in the U.S. Nat. Mus., recorded by Cope from Ripley and Lancaster. In the Cin. Soc. Nat. His., collected by Dr. Lindah1 at Cincinnati ; in Oberlin College, by Lynds Jones in Lorain Co.; in O. S. U. Mus., by E. V. Wilcox at Sugar Grove and Morgan Co.; by the author at Youngstown, Chillicothe, Worthington, Columbus, Nelsonville and in Licking Co.

Plethodon glutinosus Green. Form stout, little distinction between head, body and tail. Metallic blue above, spotted with specks of silver. Below lighter, similar in appearance to the preceding. Inner toes developed. Costal grooves I4. Length 6 inches.

This species may be confused with the sub-species Plethodon cinereus or with Amblystoma jeffersonianum. From them, however, it may be distinguished by the presence of fourteen costal grooves. It is purely a terrestrial species, a denizen of the mountains and hills. It is to be found under stones and logs on the sides of hills, often far from water. Smith ('82): "They hibernate beneath wet logs and go into the water to breed in April, in Georgia and probably a little later in our limits." Hay ('92) considers them wholly terrestrial, in all probability.

It is very common in central, eastern and southern parts of the State.

Specimens in the Oberlin College Museum, collected by Lynds Jones from Lorain Co. In the O.S. U. Mus., by the author from Youngstown, Newton Falls and Sugar Grove.

Gyrinophilus porphyriticus Green. Yellow to brown above; sides light, with a reddish tinge. Light or grey streaks and blotches on back. Costal furrows I4. Tail compressed, with a well developed keel. Body flattened. A light line from eye to edge of upper jaw. Below not spotted. Length $6 \frac{1}{2}$ inches.

Rare in the State. Intrusions are resented by snapping, and if carricd to extremes, by violent contortions. It is, however, utterly larmless. Smith ('82) gives it as aquatic, being found under logs in damp woods and in water. The adults are generally concealed, the larvae being more readily found.

Specimens in the U.S. Nat. Mus., recorded by Cope from Columbus. In the Cin. Soc. Nat. His., collected by Dr. Lindah1 in Hamilton Co.; in O. S. U. Mus., from Sugar Grove. 
Spelerpes bilineatus Green. Body yellow above, with a brown line running on each side of the median line. Below, white without yellow and without markings. The dorsal bands are made up of confluent spots which are sometimes isolated, causing the bands to be broken. The mid-dorsal region is sprinkled with brown dots. Sides mottled, Tail as long as head and body, not keeled. Costal grooves 14 . Length $3 \frac{1}{3}$ inches.

A common salamander. It is found always near running water, although seldom seen in it, but preferring to remain within ready access. A rock or stick partially placed in the water is a favorite place for concealment. In boggy areas, around springs and ravines, it is common. Its actions are quick, and this with its excessive slipperiness, renders it hard to catch. Its eggs are attached to the under side of stones partially submerged in the water. Eggs have been taken in the latter part of May. The form is distributed over the whole of the State but will be more readily found in the central and eastern portions.

Specimens in the U.S. Nat. Mus., recorded by Cope from Columbus, Cleveland and Cincinnati. In the Cin. Soc. Nat. His., collected by J. C. Galloway in Montgomery Co.; in O. S. U. Mus., by the author at Sugar Grove, Worthington, Youngstown, Chillicothe and Licking Co.

Spelerpes longicaudus Green. Resembling in a way the foregoing, but tail nearly twice length of head and body. Yellow deeper with irregular black markings. A series of such spots runs along the median dorsal line. Below immaculate. Tail compressed, keeled, spotted as above. Length $5 \frac{1}{3}$ inches.

A terrestrial species. Unlike bilineatus, it is found generally away from water, being concealed under logs and stones. In August, at Youngstown, the writer found it abundant along Mill Creek in piles of stones near the water. On being disturbed they would seldom run towards the water but generally in an opposite direction. The common name "Cave Salamander" is a misnomer, as it is seldom found in caves. Smith ('82) gives it as aquatic, which is certainly a mistake. Vide Garman ('9I): Very common over the State.

Specimens in the U. S. Nat. Mus., recorded by Cope from Cincinnati, Columbus, Lancaster and Highland Co. In the Cin. Soc. Nat. His., collected by Dr. Lindahl from Hamilton and Montgomery Cos.; in O. S. U. Mus., collected by E. V. Wilcox at Ellis Station; Dr. Smith at Lancaster, and by the author at Youngstown and Chillicothe. Also at Sugar Grove. 
Spelerpes ruber ruber Daudin. Body vermilion, spotted with black dots above. Sometimes the spots are confluent. Below the dots are smaller and more closely packed together. Head broad and blunt; dark bar across eye. Tail short. Length 6 inches. Costal grooves I5.

A most beautiful animal. It is a most conspicuous object when uncovered amongst stones and leaves, and whatever use the color subserves, it certainly is not protective, unless as a warning. They will remain motionless when uncovered until touched, when they move leisurely away. It occurs in hilly regions and is aquatic, being found in swamps and around springs. In the hilly regions of the State, common.

Specimens in the U. S. Nat. Mus., recorded by Cope from Cincinnati and Columbus. In Oberlin College, collected by Lynds Jones in Lorain Co.; in O. S. U. Mus., from Fairfield Co., and by the author in Licking Co.

\section{Family: DesmognathidaE.}

Desmognathus ochrophaea Cope. Brownish, yellow dorsally, brown laterally. Median dorsal band yellow, with black blotches and dots. Below yellowish, unspotted. Costal folds 13. Size small. Tail cylindrical. No teeth in rear of lower jaw. Length 3 inches.

This salamander may be confused with Spelerpes bilineatus or with Desmognathus fusca. From the former it may be told by the yellow on the belly and the presence of a light bar from eye to cormer of mouth. From the latter, it is readily told by the rounded tail and (in males) by the absence of teeth in the rear of the lower jaw.

It is an eastern species, a resident of the mountains and is placed here on the strength of a single specimen taken at Sugar Grove, December, 'or, which agrees with Cope's description. Dr. J. Lindahl, of the Cin. Soc. N. H., kindly examined the specimen and agreed with the writer in his identification. Previously it has not been recorded west of the mountains of Pennsylvania. Its habitat is given by Paulmier ('O2) as " under bark ; not aquatic." 'The Sugar Grove specimen was taken far up on a hill, far from the water-a most anomalous place for $D$. fusca, if such it is.

In O. S. U. Mus., collected by the author at Sugar Grove. 
Desmognathus fusca fusca Raf. Above dark, with a median dorsal band of lighter generally brown in color and specked with black. Below grey with black specks forming a marbling. Often the ground color above is brown, the median band being a lighter brown on the belly, the light predominating. Very variable in color. Costal grooves 14 . Length $4 \frac{1}{2}$ inches.

The sub-species jusca, the commonest of our more aquatic salamanders, is distinguishable from the following sub-species, auriculata, by the absence of a series of reddish spots along the sides and also of a conspicuous ear-spot, the latter giving auriculata its sub-specific name. As fusca grows older, it becomes darker and darker, the several markings becoming less and less conspicuous. It may be found almost anywhere where a stream of water flows over rocks that may give it shelter. On turning over stones, not completely submerged, a specimen or two of this salamander generally is seen making for the water which affords it concealment. As soon as the intruder withdraws, the salamander emerges from the water and takes its station beneath a convenient stone. In breeding season, the female lies concealed under a stone with the eggs either wrapped in strings about her body or herself curled about the mass.

In Ohio this is the prevalent form and is very common in all parts of the State. The larvae attain a length of three inches before becoming mature and inhabit springs and small bodies of water. They are brown, with black dots above, lighter below, retaining also the black dotting. The gills are short and inconspicuous. Sometimes the back is dotted here and there with livid specks of red, but this disappears in the adult condition. These larvae are the conmmon "lizards" of springs and are held to be poisonous. Of course they are absolutely harmless.

Specimens in the U.S. Nat. Mus., recorded by Cope from Columbus, Highl tnd Co. and Cincinnati. In the O. S. U. Mus., collected by J. C. Bridwell at IDublin; E. V. Wilcox in Warren Co.; by the author at Sugar Grove, Youngstown, Chillicothe, Newton Falls and Licking and Perry Cos.

Desmognathus fusca auriculata Holb. As above, but darker, with a series of red dots along the sides and a black ear-spot. Dark predominant below.

Not common in the State. One specimen in U. S. N. M. from Cincinnati. Habits as above. A form found in the South and West.

In U. S. Nat. Mus., recorded by Cope from Cincinnati. 


\section{Family: PleURODELIDAE.}

Diemyctylus viridescens viridescens Raf. Toes $4-5$, outer and inner toes on hind foot rudimentary. Body above brown to olive, below yellowish. Sides of adults with a series of large red spots, each encircled by a brown ring. Below speckled with brown. Tail much compressed. Length $3 \frac{1}{2}$ inches.

This sub-species is the common Newt of the Eastern States. It is altogether aquatic, living in springs and deep running water. In Ohio it is known from but one specimen from Lancaster, mentioned by Wilcox ('9r).

In O. S. U. Mus., collected by E. V. Wilcox at Lancaster.

Diemyctylus viridescens miniatus Raf. Similar to above, but ground color, brick red. The red coloring of the lateral spots therefore is less conspicuous. The skin is rough, being covered with minute warts. Tail cylindrical.

This is the common representative of the genus in the State. It is never found in numbers but may be looked for in all parts of Ohio. It occurs under rotten logs, in stumps and under stones often far from water. The form is very conspicuous and stands out from its environment very decidedly. It is not active in its movements and may be readily captured. The tongue is free and by means of that organ the food is obtained in the manner of the common toad.

Specimens in the U.S. Nat. Mus., recorded by Cope from Cincinnati. In Oberlin College by Lynds Jones from Lorain Co.; in Cin. Soc. Nat. His., collected by E. E. Masterman at New London ; in O. S. U. Mus., collected at Lancaster by E. V. Wilcox; at Clintonville by J. C. Bridwell, and at Newton Falls by the author. Also reported from Sugar Grove.

\section{Order: SALIEN'TIA Laurenti.}

This order includes the toads and frogs, $i . e_{\text {. }}$, the tailless Batrachia. The larvae are similar to those of the order just completed, being provided with gills and spending their larval period in water, feeding on vegetable matter. They are commonly known as "tad-poles." When metamorphosis takes place, they leave the water, losing the gills and the tail and gaining four strong legs and a pair of lungs; the alimentary canal becomes shortened for a carnivorous habit. The order is divisible on anatomical and physiological grounds into two tribes, viz: 
I. Thoracic region capable of expansion by virtue of the fact that the cartilage connecting the two clavicles and coracoids in the median line is double, the two parts sliding on each other.-ARCIFERA.

2. Thorax not capable of expansion because the cartilage is single and immovable.-FIRMISTERNIA.

The Arcifera embraces the tree-toads and toads; the Firmisternia, the frogs.

\section{Tribe: ArCIFERA.}

\section{Family: BufonidaE.}

Bufo lentiginosus americanus (Le C.). Brownish to olive, vertebral line yellowish. Adults with skin covered with warts of varying size. Head $4 \frac{1}{2}$ times in total length of body. Below yellowish. Bony ridges above and. behind eye; eye small. Length $3 \frac{1}{2}$ inches.

This is the common toad in Ohio. It is extremely variable, both in point of structure and color. At Cedar Point, Sandusky, Ohio, the majority of the toads found are light grey in color, whereas on the mainland around Sandusky, where a more humid condition obtains, a dark brown color is prevalent among the toads. A reddish hue is sometimes met with in the toads on the bleak hills in southern and south-eastern Ohio. Thus at Nelsonville the writer obtained several brick-red specimens. In each case the color must have been assumed after the adult condition had been reached since the young were of a uniform brownish or olive color. The specimen labeled Bufo lentiginosus lentiginosus Shaw, in the O. S. U. Zoological Museum from Columbus and Knox Co., is referable to the sub-species americanus. (Morse, 'or, May.)

Toads lay their eggs as soon as the warmer weather of spring begins. The eggs are laid in strings which are wrapped around water weeds and debris in general in small running streams. The eggs are smaller than those of the frogs, the latter being laid in mulberry-like masses, by which the two may be distinguished

Wilcox ('9I) records a specimen taken on November 29th, while another was captured January roth. These are extreme dates as toads generally appear for the first time about April rst, and begin to hibernate in October. 
The toad is one of our best friends inasmuch as the number of flies and insects that he devours daily is prodigious. It is needless to say in this connection that the superstition that holds among many, that evil effects will follow the killing of a toad is a most advantageous belief, but bears a different interpretation. Did there exist more such superstitions the cause of scientific agriculture would be strengthened tenfold.

Generally distributed over the State, common everywhere.

Specimens in the U. S. Nat. Mus., recorded by Cope from Marietta. In the Oberlin College Museum, collected by Lynds Jones from Lorain Co.; in O. S. U. Mus., collected by the author at Cedar Point, Vinton, Youngstown, Chillicothe, Newton Falls and Licking Co.

\section{Family: Hylidae.}

Acris gryllus crepitans Baird. Above olive-brown, with an inverted "Y "-shaped green area; the median parts of the " $\mathrm{Y}$ " extend along the vertebral line, the forking taking place on the rump. Brown triangle between eyes. Sides marked with three oblong blotches. White line from eye to shoulder. Disks of fingers small, not webbed. Toes with broad webs. Snout blunt. Inner surface of thigh inmaculate. Length $1 \frac{1}{3}$ inch.

The Cricket-frog is well known to anyone who frequents the river-side or the swamp--less, however, by its appearance than its note. If one can imagine a rattling of pebbles mingled with the screech of a violin string in a high note, he may have a suggestion of the Cricket-frog's note. When given it is either a continuous chirp or given in sets of chirps of three each, each rising in pitch. So nearly does the color of the frog blend with that of its surroundings that it is detected with but the greatest difficulty.

In the Cricket-frog we have virtually a Tree-frog with terrestrial habits. The presence of the terminal suckers on the toes would seem to indicate a former arboreal mode of life. Common everywhere.

Specimens in O. S. U. Museum from Central College, Franklin, Delaware, Lawrence, Warren, Fairfield, Ottawa and Knox Cos., and collected by the author from Ross and Trumbull Cos., and at Youngstown, Newark and Vinton.

Chorophilus triseriatus Wied. Toes scarcely webbed; fingers without webs. Ground color above ashy, with a brownish median dorsal stripe, dividing into two above in middle of body. Lateral to this on either side and running parallel on level with ear is a brownish stripe. A third stripe runs along the sides of the head from the snout backward, making in all six stripes running more or less parallel: Length $\mathrm{I}$ inch. 
This is the so-called " Little Tree-Toad," a name that would probably be appropriate if the little fellow ever climbed trees! It is to be found in swamps on low herbage or on the ground. It has a note somewhat similar to the preceding species, but the pitch is higher and the rattle is less definite. The note is seldom heard in daylight hours except on dark days. The writer has never heard it, as Cope says, in the hottest hours.

Smith ('82) gives this form as rare in Ohio. At the present time this is scarcely true since it has been found common in various parts of the State. Thus along the Ohio shore of Lake Erie it is common in the swamps. Prof. J. S. Hine found several at Kent, and in the north-eastern part of the State.

The species is very variable. An extreme was taken on Cedar Point, Sandusky, which was brick-red all over, with the faintest hint at the dorsal bifurcated marking.

Cope ('89, p. 339) gives as a species distinct from triseriatus Wied., the species Jeriarum Baird. Hay (v., Jordan, '99, p. 360), however, considers these two species as simply varieties of nigvitus Le C. He would make, then, our eastern form $C$. nigritus feriarum (Baird).

Specimens in Oberlin College, collected by Lynds Jones in Lorain Co. In O. S. U. Mus., collected by J. S. Hine at Kent, and by the author at Cedar Point; also at Sugar Grove.

Hyla pickeringii Storer. Disks on fingers and toes large and conspicuous. Skin rough. Toes webbed. Ground color above, yellowish, with two narrow lines, forming an oblique cross, darker in color. Brownish blotches also on dorsal surface. Below yellowish. Lines along sides of head. Legs barred. Length I inch.

In the spring and summer this little animal is to be found in moist places among fallen leaves. As fall approaches it ascends trees where it remains until hibernation time, which is late, since it is quite hardy. Its note is a squeak combined with a whistle, and, as Cope says, "bearing considerable resemblance to the note of the Purple Finch."'

Found only here and there over the State. It seems to be erratic in point of occurrence, although in the States east of Ohio it is common.

Specimens in the U. S. Nat. Mus., recorded by Cope from Marietta. In Oberlin College, collected by Lynds Jones in Lorain Co. In O. S. U. Mus., collected by E. V. Wilcox at Hanging Rock and Sugar Grove. 
Hyla versicolor Le Conte. Skin granular above, colored ash-gray to brown. Superciliary lines of brown, converging on back. In middle of back an H-shaped brown blotch. Yellow below. Ear large. Fingers onethird webbed; discs large. Length 2 inches.

This is the common Tree-toad with its reputed prognosticating powers with respect to the weather. That the toad foretells a period of rain by its chirping is a myth of the first magnitude. If there be any foundation of truth in the matter, the Tree-toad chirps only toward evening or when clouds obscure the sun, the latter being a condition concomitant with rain. A clear evening following a rain is par excellence the Tree-toad's hour of song.

The toad has, to a limited extent, the power of changing the the color of its skin similar to the Chameleon, but it is a matter of chance that it assumes the color of the substratum. Common everywhere.

Specimens in Oberlin College Museum, collected by Lynds Jones from Lorain Co. In O. S. U. Mus., collected by E. V. Wilcox at Westerville and Columbus; by the author at Vinton, Chillicothe, Youngstown and Licking Co.

\section{Tribe: FIRMISTERNIA.}

Including the remaining BATRACHIA, the Frogs.

\section{Family: RANIDAE.}

Rana virescens virescens Kalm. Green above, with irregular black or brownish blotches with white edges arranged in two irregular rows, the blotches alternating. Two spots between eyes. Front of thigh with a longitudinal band of brown. Head short. Length 3 inches.

The common frog of river, stream and swamp. Often found in thick grass far from water, perhaps migrating. Abundant everywhere.

Specimens in Oberlin College Museum, collected by Lynds Jones in Lorain Co. In O. S. U. Museum, by E. V. Wilcox at Gypsum and Sugar Grove; by the author at Vinton and Youngstown.

* Rana virescens brachycephala Cope. Form with shorter head ( $31 / 2$ times in length of body). Spots on upper part of body larger. Transverselyrunning markings on crux not interrupted. No longitudinal band on anterior border of thigh.

. Given by Cope (' 89, p. 403) as ranging from Massachusetts to the Sierras. No record for Ohio. 
Rana palustris Le Conte. Similar in coloration to preceding save that the dorsal blotches are arranged in two longitudinal series, each blotch being approximately opposite its fellow. The livid green, however, is replaced here with brownish or olive. Length 3 inches.

The Swamp-frog is to be found in marshy places, but it is frequently met with in high grass in fields and along roadsides. It is much commoner than would be supposed as it is with difficulty distinguished from its environment and unlike the foregoing species, it remains quiet until almost touched. Common over the entire State.

Specimens in the U. S. Nat. Mus., recorded by Cope from Toledo. In the O. S. U. Mus., collected by J C. Bridwell at Dublin and by E. V. Wilcox in Ottawa, Lawrence, Franklin and Delaware Cos.; by the author at Sugar Grove and Gypsum.

* Rana septentrionalis Baird. Olive brown above, light yellow below. Back with irregular streaks. Length $I \frac{1}{2}$ inches. Skin smooth. Eye large.

This species has never been taken within the limits of the State, but owing to its range it very probably will be found in the north-eastern or eastern portion. Its range is northward from Minn. to N. Y.

Rana clamata Daudin. Uniform brownish green, with faint black spots. Below white. Ear large, as large as eye. First finger reaching end of second. Length 3 inches.

This is a heavier frog than any that have thus far been considered. It is somewhat gregarious, especially in spring and early summer. It is never found far from water. This species is the least noisy of the genus, its note being a miniature of the Bullfrog's gutteral croak. The conspicuous lateral fold distinguishes it from the Bull-frog. Abundant over the State.

Specimens in the U. S. Nat. Mus., recorded by Cope from Columbus and Portage and Highland Cos. In the O. S. U. Mus., collected by E. V. Wilcox in Lawrence and Licking Cos. By the author at Vinton, Castalia, Newton Falls and Chillicothe.

Rana catesbiana Shaw. Lateral fold scarcely discernable. Above brown to olive, interspersed with brownish blotches, sometimes running together. Head bright green. Ear large. Toes with web reaching the tips. Length $5-8$ inches.

This is the common Bull-frog, the largest of our frogs. and of the Batrachia in general. It is seldom seen but is to be heard 
along almost any of our streams. At times of high water these big frogs leave the inundated regions and migrate to higher ground. They are caught for the market in great numbers, and were it not for their great fertility, they would soon become extinct, as indeed is the case in some parts of the country. Frog farms exist to supply the market and when well conducted are ready sources of revenue. Common over the State.

Specimens in the U. S. Nat. Mus., recorded by Cope from Marietta and Elyria. In the O. S. U. Mus., collected by R. C. Osburn at Columbus, and by E. V. Wilcox at Central College and Lake Erie.

Rana sylvatica Le Conte. Sides of head with a chocolate band running from snout backward. Below this a light line. Brownish spot on base of arm. Above brown, below lighter. Lower jaw mottled in front with brown. Lateral fold brown, conspicuous. Legs barred transversely. Length $\mathrm{I} 1 / 2$ inches.

The Wood-frog is, in the mind of the writer, the most beautiful of the frogs. It cannot be confused with any other species when the markings are considered. It is an anomaly among its brethren inasmuch as it is never found in the immediate vicinity of water after the eggs have been laid in the early spring. Its home is among the fallen leaves of an upland woodland where it lives a solitary life. It is extremely hard to distinguish among the leaves as protective coloration is so well developed.

Kirtland (' 38 ) gives the following note under this species: "It is impossible to move in our Ohio woods during summer without stepping on them, they are so abundant." Whether this was meant to apply to the whole of Dr. Kirtland's period of observation or to a limited period is not evident. What is evident, however, is that there has most certainly been a marked change in the distribution of the species since 1838 , for as it occurs now in our State it is found as isolated individuals. Only during breeding seasons do they become in any sense gregarious and this only for a few weeks in early spring.

Found over the entire State, but erratic, occurring only as isolated individuals.

Specimens in the U. S. Nat. Mus., recorded by Cope from Yellow Creek and Toledo. In Oberlin College, collected by Lynds Jones, Lorain Co. Sandusky High School, by E. L. Moseley, Sandusky. O. S. U. Museum, by E. V. Wilcox in Lawrence, Warren and Delaware Cos.; by the author at Gahanna and in Licking Co. Also reported from Knox and Fairfield Cos. 


\section{Class: REPTILIA.}

But one fossil reptile is known from an Ohio formation, this being a portion of the anterior end of an animal together with a portion of the vertebral column and the right posterior leg, showing crux and tarsalia. The specimen was taken at Linton, Ohio. It is considered by Cope as the only reptile positively identified from the Coal Measures and therefore the oldest known reptile. In speaking above ${ }^{8}$ regarding the fossil Batrachia, an attempt was made to correlate the horizon at Linton, from which the several specimens were taken, with the Permian. In case the identification is correct, the statement of Cope would not be true, since the Theromorpha embraces many families found in the Permian of both the old and new worlds.

\section{Order: THEROMORPHA Cope.}

Family: PARIOTICHIDAe Cope.

Isodectes punctulatus Cope, Proc. Amer. Phil. Soc., 36:88.

\section{Order: SQUAMATA Latr.}

\section{Family: Iguanidae.}

Sceloporous undulatus undulatus Latr. Above brownish olive, with undulating brown cross bars edged with livid green. Legs similarly transversely banded. Throat and sides of chest bright blue, scales keeled. Head somewhat flattened. Length 7 inches.

The Pine-tree lizard is common in the non-glaciated region of Ohio, its range in the State being limited, in the main, by the glacial boundary. It is a beautiful object, a statement, could antipathy be overcome, no one would care to gainsay. It is extremely quick in its movements and therefore difficult to capture. The vertebrae of the tail are so constructed that that appendage may be readily parted with, with whatever disadvantage, gaining the life of its owner.

This little animal is absolutely harmless and makes an excellent pet.

Specimens in the U. S. Nat. Mus., recorded by Cope from Columbus. In Cin. Soc. Nat. His., collected by Dr. Lindahl at Cincinnati; in O. S. U. Mus., by J. S. Hine at Vinton, and by the author from Chillicothe and Fairfield Co. Also recorded from Sugar Grove.

\footnotetext{
8. Supra, p. 105 .
} 


\section{Family: Anguidae.}

Ophisaurus ventralis Linn. Olive-green or brown, yellowish below. Legs wanting, body snake-like. Tongue not cleft as in snakes. Preanal scales generally eight (8) in number. A conspicuous fold along sides. Tail very brittle. Length 2 feet.

The Glass-snake derives its name from the readiness with which the tail breaks in pieces. This is due to the fact that the vertebrae in the tail are bony only at their ends, the centres remaining unossified and hence are readily separable. Although a snake in appearance, it is yet a lizard without legs. It may be told at once from any other Ohio reptile by its snake-like appearance and its non-forked tongue.

It is included here on the strength of a single specimen taken on the University farm by Dr. Townshend and is at present in the O. S. U. Zool. Mus. It was killed in a hay field, having been shaken out of a stack of hay. That it is valid is certain and it is but a few hundred miles out of its usual range. Hay ('92, p. 542 ) gives it as occurring in northern Indiana.

In the O. S. U. Mus., collected by Dr. Townshend at Columbus.

\section{Family: TEIDAE.}

*Cnemidophorus sexlineatus (L.). Brownish above, with six dorsal streaks. A silvery spot on throat. A median dorsal band of brown. Tongue bifid, snake-like. A double fold across neck. Length 6-7 inches.

This is a very common form within its range, which is, in the main, southerly and westerly. It occurs from New Jersey to the mountains in the West. It has no Ohio record.

\section{Family: ScINCIDAE.}

*Liolepisma laterale Say. Head angular, pyramid-shaped, with apex directed forward. Above reddish-olive to bronze or greenish. A light line on sides, below which, on level of eye runs a second darker line, while below the two, a white line. Ventro-laterally, striped alternately light and dark. Under parts yellowish. Tail blue below. Length 5 inches.

This is a Southern form, straggling north to Indiana. Its status as an Ohio lizard is not without question. Smith ('82) states that he has not seen it from the State. Kirtland (' 38 ) speaks of it in a note as follows: "S. lateralis was shown to me by Mr. Dorfeuille, as an inhabitant of Ohio." Dorfeüille was a 
citizen of Cincinnati and a naturalist of some ability. In 1835 he owned a private museum in that city which, on his death; was lost to science by the specimens being promiscously distributed or destroyed. Nothing now is known of the museum and hence his record of the species in question is based solely on Kirtland's assertion. That it should occur in Ohio is not strange since Robert Ridgway took it at Wheatland, Ind. Prof. J. S. Hine, of the Qhio State University, believes that he has seen it at Ft. Ancient, near Cincinnati.

Eumeces quinquelineatus L. Above black, with five longitudinal yellow streaks, one median and two lateral on either side. The median stripe bifurcates on occiput, each branch running to rostrum. Variable with respect to the color, the stripes being sometimes obsolete, while the ground color becomes reddish. Tail brilliant blue. Length II inches.

The Blue-tailed Skink is a beautiful little animal. When in the woods one often catches a glimpse of a train of livid green, resplendent in the sun shooting across his path-a glimpse only, for once among the fallen leaves search for the skink is useless. They readily part with a portion of their tail to a would-be captor. During the darker hours and during cloudy weather they secrete themselves beneath loose bark or among fallen leaves.

In the State the skink is common, but is never conspicuous, and therefore is generally unknown to the farmer.

Specimens in the Cin. Soc. Nat. His., collected by Dr. Lindahl in Hamilton Co. In O. S. U. Mus., collected by Chas. W. Souder in Franklin Co.; by the author at Chillicothe.

*Eumeces anthracinus (Baird). Similar to the foregoing save that there are only four stripes, the interspaces being coal black.

Given by Cope ('oo, p. 66r) and Jordan ('99) as having a range from Pennsylvania to Missouri, and hence may be found within the State's limits. No specimen, however, has been taken in the State.

\section{Order: SERPENTES Wagler.}

\section{Family: ColubridaE.}

Carphophiops amoenus Say. Uniform chestnut above, below uniform red. Head small, fusing with body without interpolation of neck. Scales, iridescent and glossy. Tail short. Scales I3, not keeled. Anal plate bifid. Length I foot. 
A snake too inconspicuous and uncommon for a common name. It occurs in sparse woodland and among underbrush. Sometimes it visits houses. A more inoffensive creature could not well be imagined. The species helenae Kennicott having but a single pair of frontal plates is a variation of the species under consideration. Rare in the State, but probably occurs in all parts of Ohio.

Specimens in the U. S. Nat. Mus., recorded by Cope from Morton and Ironton. Mus. of Antioch College, Yellow Springs, from Yellow Springs. In O. S. U. Mus., from Meigs Co.

Diadophis regalis arnyi Kenn. Slender; above leaden black, below yellow, thickly spotted with black. An occipital ring light yellow. Scales smooth, I7. Length 2 feet.

Ohio seems to be the eastern limit of this form. It is recorded for the State in but one place, viz.:

Specimens in U.S. Nat. Mus., recorded by Cope from Hughes.

Diadophis punctatus Linn. Tail short, below yellowish-orange, without spots save at times a faint median series. Above blue-black. A yellowish to salmon red occipital ring. Tail beneath unspotted. Scales smooth, 15. Length $I \frac{1}{2}$ feet.

A beautiful snake. Found in hilly regions, often under bark or under rotten logs. Its food consists of insects, toads, etc. It may be handled without its manifesting any annoyance. It lies quiet during the daytime and forages at night. It breeds in June. Rare in the State.

Specimens in the U. S. Nat. Mus., recorded by Cope from Marietta and Cleveland. In the Cin. Soc. Nat. His., collected by Dr. Lindahl in Hamilton Co. In O. S. U. Mus., collected by the author from Fairfield Co.

Heterodon platyrhinus Latr. Occurs in two forms, normal and melanistic. Former as follows: Above brownish, with a series of irregular dark blotches replaced on tail by saddle-shaped blotches. Below greenish yellow. Snout recurved, forming a "rooter." Scales keeled, 25. Ana1 plate bifid. Second form above uniform blue-black, below greenish. Length nearly $2 \frac{1}{2}$ feet.

The Blow-viper, of all its kindred, is most persecuted. Absolutely harmless, it is killed at sight. 'In a way it is responsible, for its attempts at bluffing and passing itself off as a dreadful creature have rather tended to heap abuse upon it. When approached it will lie quiet until assured that its presence is known 
when it will begin to hiss, inflate its body and extend its ribs until it is a minature cobra. When teased it will strike, but the stroke is but a half one, degenerating into a twist which sends the body away from its apparent victim. When teased to an extreme it will throw itself on its back after passing through a series of contortions and frothing at the mouth. Once on its back it lies as dead, without a motion and with open mouth. It will remain thus until all is quiet, when with a sly twist it surveys the surroundings and if no offender is near it silently flops upon its belly and beats a hasty retreat. Should any intruder appear it immediately throws itself upon its back again and feints death anew.

Its eggs are laid in the sand. They are about an inch long and half an inch wide. It is very common in hilly and sandy regions. By the countryman it is often confused with the copperhead, which it resembles somewhat, or even it may be that the dangerous copperhead is called blow-viper and held to be harmless, as the writer found to be the case among some farmers in the eastern part of the State. In such cases it would be safer to assume that all snakes were dangerous than to confuse poisonous and non-poisonous.

The food of the Blow-viper consists of mice, toads, frogs, insects, etc. It is one of the most valuable reptiles to the farmer owing to its food habits.

Very common over the eastern and northern parts of the State, rarer west.

Specimens in the U. S. Nat. Mus., recorded by Cope from Marietta. In the Cin. Soc. Nat. His., collected by Dr. Lindahl in Hamilton Co. In O. S. U. Mus., by the author at Sandusky and Licking Co.

Liopeltis vernalis De Kay. Uniform dark green above, lighter on sides; below yellowish white. Head long, marked off from body by a slender neck. Eyes large. Scales smooth, 15. Length 20 inches.

This snake is common over the State, but is seldom noticed by one unless especially looking for it, as protective coloration is carried to such a degree in it that it blends perfectly with the surroundings. It is seldom seen in the daytime, but is to be found at dusk or during the early evening hours when it goes in search of food. Its food is largely made up of insects. 
Smith ('82) gives it as frequenting marshes. It sometimes is seen on low bushes. It may be distinguished from the following by its smooth scales.

Specimens in the U. S. Nat. Mus., recorded by Cope from Columbus. Cin. Soc. Nat. His., collected by Dr. Lindahl from Hamilton Co. In O. S. U. Mus., by E. L. Moseley from Sandusky, and by E. F. Crans from Ira, Summit Co.

Cyclophis aestivus L. Scales keeled. Brilliant green above, yellowish below. Scales 17 . Neck quite small. Length 33 inches.

Habits similar to preceding species. It frequents drier ground than vernalis, however. Like it, also, it is docile and readily handled. Not common in Ohio; a southern form.

Specimens in the Cin. Soc. Nat. His., collected by Dr. Lindahl in Hamilton Co. In O. S. U. Mus., by Prof. Tuttle at Ironton.

Bascanion constrictor L. Glossy blue to black, changing to greenish below. Anteriorly, belly and throat light. Scales smooth, I7 or I9. Body long and slender, eye large. Length 5 feet. Young differing from adults by having brown ground color above with black blotches.

The Black-snake or Blue-Racer is one of our largest snakes. It is a familiar animal, occurring over the whole of the State. It is generally found in woodland, although it may be met with in meadows or on roadsides. Its food, consisting as it does of mice, rats, insects, etc., makes it a valuable vermin-destroyer, but few are the farmers that pass one by without destroying it. As to the tales of its prodigious strength whereby it can crush a man by wrapping itself around him it may be said that they are without foundation. This snake is a splendid tree-climber, running up a tree trunk by means of projecting knots and limbs with readiness. If the Blue-racer can be arraigned for any misdeed it is his love of eggs, and hen's nests often pay high for his retention on the farm. Kirtland (' 38 ) mentions this snake as on the increase as the country becomes cleared.

Specimens in the U.S. Nat. Mus., recorded by Cope from Hughes, Salt Creek and Delaware Co. In O. S. U. Mus., collected by W. H. Smith at London and Lancaster, and by the author at Cedar Point. Also reported from Hocking Co.

Coluber vulpinus B. \& G. Above yellow, with a median series of large, irregular, chocolate blotches and a lateral series of smaller alternating with the larger ones. Head copper-colored above. Below yellow, with rectangular, black spots forming a checker-board appearance. Scales smooth, 25. Length 5 feet. 
The Fox-snake is like the last, a large snake. It is a denizen of woodland areas and a splendid tree-climber. The writer watched a five-foot specimen crawl up a small elm tree. It used its head as a fulcrum to a large extent and would take advantage of the least irregularity in the bark as a means of aiding its ascent.

The range of this snake has been a matter of dispute, but now it seems that Ohio holds the eastern-most record. Cope ('oo) asserts that it does not occur east of Illinois, but it occurs throughout Indiana and northern Ohio. For a full consideration of the case the reader is referred to "Science," Vol. XV, page I034, where the present writer reviews the matter in question. The snake is common in the northern part of the State, but does not occur in central or eastern Ohio.

Specimens in the O. S. U. Mus., collected by Seth Hayes at Cedar Point, and by the author at Castalia.

Coluber obsoletus obsoletus Say. Above brownish black, scales edged with white. A series of irregular, quadrate blotches with a series of smaller blotches lateral to and alternating with them, both being at times obscure or even obsolete. Median scales somewhat keeled, the remainder smooth. Below very dark brown, somewhat mottled. Scales 27. Length 6 feet or over.

This is our largest snake. The vernacular name is Pilot Black-snake. It is to be found only in wooded areas and seems to retreat to the heaviest forests with the advent of the axe. It is easily handled and makes little defence when captured. They are often found sunning themselves after a period of rain.

The snake is not well known among the farmers in general, but wood-cutters in the region of native forests are familiar with it.

In the wooded areas of the State fairly common, but apparently growing rare.

Specimens in the O. S. U. Mus., collected by R. C. Osburn at Columbus; by Prof. Tuttle at Yellow Springs; by the author at Nelsonville and Licking Co.

* Pituophis melanoleucus (Daudin). Ground color above white with a series of brown blotches, bounded by black rings. Scales 29. Postorbital scales 3. Head almost white, Length, maximum 70 inches.

A resident of the pine woods and wooded sandy regions. Its range is southerly. The Pine or Bull-snake, as it is called, has no Ohio record. 
Osceola doliata triangula Boie. Ground color greyish, with a series of median dorsal blotches of brown edged with black. A series of smaller blotches lie lateral to these and alternate with them. Occipital spot triangular. Below yellowish, with quadrate black blotches. Scales 2I, smooth, Length $4 \mathrm{~T} / 2$ feet.

The Milk-snake can be confused with either the Fox-snake or the Water-snake. From the former it is readily told by its entire anal plate, while the scales in the Water-snake are keeled. The common name of the snake has nothing to do with the color, but is indicative of its habit of prying around milk-houses. It is often found in houses in the country where it doubtless wanders for food. It is absolutely harmless. Common all over the State.

Specimens in the U. S. Nat. Mus., recorded by Cope from Hughes. In the Cin. Soc. Nat. His., collected by Dr. Lindahl in Hamilton Co. In O. S. U. Mus., by J. S. Hine at Akron, and by the author at London and Nelsonville.

Osceola doliata doliata L. Similar to preceding, but no yellow line running back from eye along sides of head. Ground color reddish.

Rare in the State. Given in the present connection because of Specimen No. 10,084, U. S. N. M., from Hughes, Ohio, collected by R. T. Shepherd.

Ophibolus calligaster Say. Above light, with chestnut blotches arranged in three series, a median and a lateral on either side. Scales in 25 rows.

To be distinguished from the two preceding species of the genus Osceola by the number of scales. Rare in Ohio.

Specimen in O. S. U. Mus., collected by Prof. Tuttle at Lancaster.

Natrix fasciata fasciata L. Lozenge-shaped patches of black on back and sides-a single series. No alternating lateral blotches save an alternating series of lateral reddish spots. Scales keeled, 23 or 25 . Head long. A black postocular band. Length $4 \frac{1}{2}$ feet.

This is the Southern Water-snake. It is distinguishable from the following sub-species by the absence of a lateral series of blotches of black alternating. with the dorsal series.

In the State it is represented by a single specimen in the Zoological Museum of the Ohio State University from Warren County. 
Natrix fasciata sipedon L. As above, but blotches brownish and with a series of small blotches of brown alternating on the sides with the larger dorsal blotches. Below yellowish to ashy, each gastrostege, with a black quadrangular blotch. Body thick and heavy. Scales 23, sometimes 25 .

The common Water-snake is to be found in every stream of the State. It is very variable in color and markings, but cannot well be confused with any other snake. It is never found far from the water, and generally places itself so that it may, at a moment's notice, glide into that element which affords it an effective retreat. When handled it is very aggressive and strikes violently. While not poisonous, its bite is, to say the least, unpleasant, as the teeth are long and very sharp. Its food consists of fish, insects and toads.

The members of this genus are all ovoviviparous, retaining the eggs in the body until hatched. The Water-snake is held by some to swallow its young when unduly pressed. This is a mistake, and the error may be due to the observer thinking that the unhatched young in the oviducts were in the alimentary canal.

The Water-moccasin of the South is often confused with this species. The poisonous' sulake has been reported from the Ohio River near Cincinnati, but no specimens exist and it is very probable that the supposed cases are large individuals of the present species.

Specimens in the U. S. Nat. Mus., recorded by Cope from Poland, Columbus, Lima, Richland Co., and Maumee and Cuyahoga Rivers. In the Cin. Soc. Nat. His., by Dr. Lindahl at Put-in-Bay and Hamilton Co.

Natrix fasciata erythrogaster Shaw. Head long, Uniform dark bluish-black above, growing paler on sides. Below copper-colored, with a series of punctations along sides of gastrosteges. Scales 25 . Length $3 \frac{1}{2}$ feet.

The Red-bellied form of the Water-snake is limited in its range to the north-western part of the State. Among the islands of Lake Erie the writer has taken specimens. Thus at Put-inBay it is common, but sipedon is found along with it. This fact cast a doubt in the writer's mind, but careful inspection of the specimens warrants such identification. Prof. H. L. Clark ('o3) has made a statistical study of the species of Natrix occurirng in Michigan, and to it the reader is referred for a better definition. of the several forms.

Specimen in the O. S. U. Mus., collected by the author at Put-in-Bay. 
Natrix leberis L. Chestnut brown, with three black longitudinal stripes and a lateral yellowish stripe. Below yellow with a black line running along the ends of the gastrosteges. Scales 19. Length 2 feet.

Common in all parts of the State. It is often to be found hanging over a stream from projecting limbs of willows from which it glides rapidly into the water when disturbed. It bites viciously when caught and, while non-poisonous, yet inflicts an ugly wound.

Specimens in the U.S. Nat. Mus., recorded by Cope from Lima and Highland Co. In Cin. Soc. Nat. His., collected by Dr. Lindahl from Hamilton Co. In O. S. U. Mus., collected by the author at Youngstown and Chillicotle.

Natrix kirtlandii Kenn. Purplish-brown above, with four rows of black blotches, alternating one with another. Below salmon-colored, the ends of the gastrosteges being black, forming two longitudinal lines. Body flattened. Scales 19 . Length I $1 / 2$ feet.

Common in marshy land, especially in hilly regions. They lie quiet during the daytime and emerge late in the afternoon to search for food. The snake is inconspicuous and is often passed off for $N . f$. sipedon. It is variable in color, the dorsal blotches sometimes being scarcely discernable, while the red of the ventral parts may be dull or even brownish. Its habit of making the naturally flattened body flatter still by the expansion of the ribs is interesting from the point of view of the student of animal behavior. The first specimen recorded below was taken in January.

Specimens in the Cin. Soc. Nat. His., collected by Dr. Lindahl from Hamilton Co. In O. S. U. Mus., by C. R. Diltz, Perry Co.; E. E. Masterman, New London, and by the author at Sugar Grove.

Storeria dekayi Holbrook. Clay-colored above, with a light vertebral stripe and a dotted line on either side. Below ashy. A dark spot on either side of occiput. Scales keeled, anal plate double. Scales I7. Length I foot. The ground color above may be brownish and the streaks may become very inconspicuous or obsolete.

Not a common snake in the State. Frequents marshy land, but Hay ('92) does not bear this out. Smith ('82) gives it as occurring at Cleveland and in the north-western part of the State. It probably occurs over the whole State sparingly.

Specimens in the U.S. Nat. Mus., recorded by Cope from Columbus, Madison, Grand Rapids and Highland Co. 
Storeria occipitomaculata (Storer). Above similar to preceding. Below salmon-red. Occiput with 3 light dots. Scales keeled, I5. Length I foot.

Common over the State in dry upland woods. Its food consists of insects in the main. Smith ('82) gives it as "not rare around Columbus," At the present time it is never found in any numbers.

Specimens in the U. S. Nat. Mus., recorded by Cope from Madison, Yellow Creek and Hughes. In Cin. Soc. Nat. His., collected by Dr. Lindah1 in Hamilton Co. In O. S. U. Mus., from Sugar Grove, and collected by R. C. Osburn at Kent.

Virginia valeriae B. \& G. Greyish brown, punctated above with black. Below light yellowish. Scales 15. Length I foot.

This little snake resembles somewhat Carphophiops amoenus, but it may be readily distinguished from that species by the pepper-and-salt appearance of the back. It feeds on insects and worms. Its movements are slow and it is very shy, appearing generally towards evening.

Known for the State by but one specimen, which is its northernmost record.

Specimen in O. S. U. Mus., from Richmondale, collected by the author.

Tropidoclonium Iineatum Hall. Head small. Brown above, with 3 narrow, yellow stripes. Below yellow, spotted. Scales keeled, anal entire. Length 16 inches.

Cope ('oo) lists a specimen of this snake from Hughes, Ohio, collected by R. T. Shepherd and now in the U. S. N. M. Dr. Leonard Stejneger, Curator of Reptiles in the Museum, would identify the specimen as a species of Storeria. The species is a Western one and has not been reported in Indiana, for which reason the Ohio record is problematic.

Eutainia saurita L. Lateral stripe of yellow on third and fourth rows of dorsal scales. Chocolate-brown above, with a broad median yellow stripe. The lateral stripes subtended by one of brown. Scales somewhat rough, 19 . Length 3 feet.

Smith ('82) gives this snake as. common in Ohio, but the present writer has watched carefully for it with no success. It doubtless is to be found especially in the eastern part of the State, but certainly in no great numbers. It is said to frequent lowland woods and about water. 
Specimens in the U. S. Nat. Mus., recorded by Cope from Toledo. In the Cin. Soc. Nat. His., from Hamilton, collected by Dr. Lindahl.

Eutainia sirtalis graminea Cope. Above uniform light green; below yellow, clouded with green. No markings anywhere. Scales I9, somewhat keeled. Length 5 inches.

This Garter-snake is very common in central Ohio as well as in other parts of the State. It is not, however, the prevailing form, as sirtalis is much the more common. It is doubtless a good variety, but has been held in question by Stejneger.

Specimens in the U. S. Nat. Mus., recorded by Cope from Columbus, Cloverdale, Grand Rapids and Lima.

Eutainia sirtalis ordinata L. Stripes not evident, but the component spots distinct on sides. Gastrosteges spotted. An occipital patch of black.

This sub-species is met with in various parts of the State, but is uncommon in collections. Its status as a variety is doubtful, as intermediate forms occur ranging between sirtalis on the one hand and graminea on the other.

In O. S. U. Mus., collected by the author at Columbus.

Eutainia sirtalis sirtalis L. Spots and stripes both distinct. Above dark olive. Below greenish. A narrow vertebral line of yellow. Three series of small, square spots on the sides.

Of the four sub-species of Eutainia listed here, this is the most common. It is the type form and to it the others are to be referred. The species of Eutainia are all ovoviviparous and the young are born in great numbers, as high as eighty having been taken from a single specimen. The food consists of worms, insects, small toads, etc. They are absolutely harmless, having short teeth and also little inclination to bite.

Specimens in the U. S. Nat. Mus., recorded by Cope from Port Clinton. In the Cin. Soc. Nat. His., collected by Dr. Lindahl from Hamilton Co. In O. S. U. Mus., from Columbus, Yellow Springs and Lancaster.

Eutainia sirtalis obscura Cope. As above, but with the spots entirely obscured. Body blackish between the well defined stripes of yellow. Gastrosteges spotted at the lateral ends.

Not a common variety in the State. The specimens that were taken by the writer were found in lowland regions.

In O. S. U. Mus., collected by the author at Columbus and Sandusky. 


\section{Family: CROTALIDAE.}

This family embraces all of our poisonous snakes. One character is present in them which is found in none of the nonpoisonous snakes and hence is an excellent criterion by which one may tell poisonous from non-poisonous forms. Between the eye and the nostril (Fig. I) on either side is a deep pit that is simply an infolded part of the skin in that region. The function of the pit is not known. It has, however, embedded in its walls, termini of nerves which would suggest that it was a sense-organ, of the same category, perhaps, as Leydig's corpuscles.

The fangs (Figs. 2 and 3 ) of the poisonous snakes are simply long, sharp teeth in the upper jaw, perforated with a tube $\left(a^{\prime}\right)$ that connects with the duct of the poison gland $(a)$, the whole forming a hypodermic injection apparatus. The poison gland (a) lies above and posterior to the base of the fangs. Above and below it run two large muscles ( $b$ and $i$ ) which serve to compress the gland and force out the venom. Should a fang be broken off another stands ready to replace it, (Fig. 3.) In our poisonous snakes the fangs are borne on the maxillary bone, which is hinged so that the teeth may be folded back and drawn into a sheath. (Fig. 2, f.)

When disturbed these snakes throw themselves into a coil from which they strike at the intruder by suddenly straightening the body. They are not able, however, to strike more than half their length, so that a four-foot snake could strike but two feet from coil.

All our venomous reptiles are sluggish and will strike only when annoyed. The Rattle-snakes are provided with a series of chitinous "rattles," which are simply modified scales. These grow on the end of the tail, being formed continuously. The first one formed in the young snake is known as the "button," it being smaller than the subsequent ones. The rattles are frequently broken off, as may well be supposed. The age of the animal hence, for this reason alone cannot be told from the number of rattles even if one rattle were formed a year, which is by no means the case since they vary in their periods of growth. Thus, at times, two or more rattles may be formed within a twelve-month or but one. It may be said that a rattle is formed at each hedding of the skin. 
PLATE II.

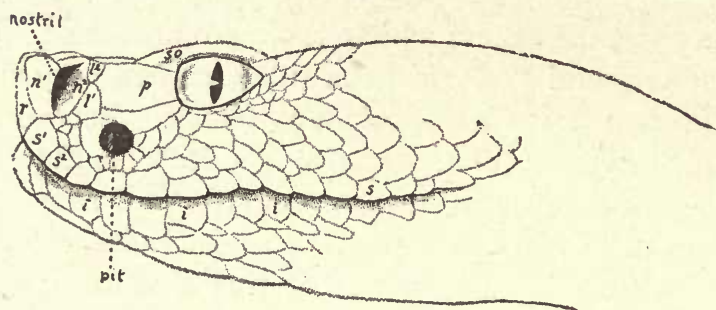

Fig. I. EXTERNAI, VIEW OF RatTleE'S HEAD.

The pit is seen between and below the eye and nostril. (From Stejneger.)

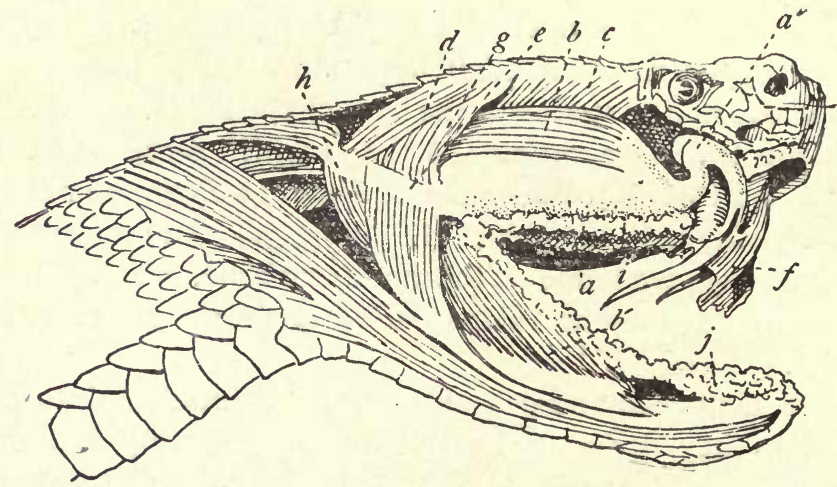

Fig. 2. HEAD OF RATTLER.

$a$, venom gland; $a^{\prime}$, duct ; $b b^{\prime}$, temporal muscle; $f$, sheath of fang.

(After Stejneger from Duvernoy.)

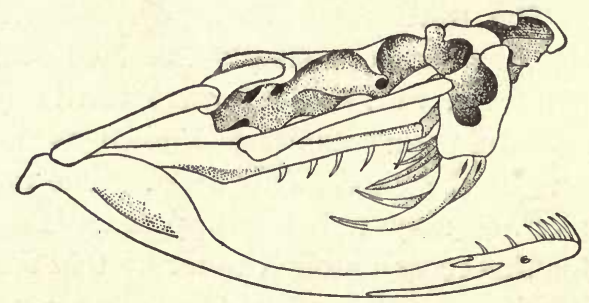

Fig. 3. SKULI, OF RATTLER-(from side.)

The long fangs in the upper jaw are fixed in the maxillary bone; this bone is hinged on the lachrymal (above) and the pterygoids (posteriorly).

The excavation for the pit in the maxillary bone is seen at the end of the pterygoid bones. (From Stejneger after Jan.) 
Ancistrodon contortrix L. Above light hazel brown, becoming coppery on the head; everywhere spotted with minute black dots. A series of darker brown, V-shaped blotches alternating with one another on either side. Below yellowish, with black quadrangular blotches. Scales 23. Length $3 \frac{1}{2}$ feet.

This is the dangerous Copper-head. It is a frequenter of low, swampy places in hilly regions. It is not confined to damp soils, however, but wanders over the uplands except in the hottest summer months. It strikes, when approached, without warning and, while its teeth are but half an inch long, they are exceedingly sharp and may even penetrate leather. The venom is perhaps not as active as that of the Rattlers, but nevertheless a small amount, properly injected is almost certain death. The snake never reaches a length of over $3 \frac{1}{2}$ feet, and this is uncommon, the normal being $23 / 4$ feet.

In the State the Copper-head occurs mainly in the southern and eastern portions, among the hills. It is never what may be called common, but individuals are frequently killed in the region mentioned. The snake is not as common as formerly and is undergoing certain extermination.

Specimens in the Museum of the Cin. Soc. Nat. His., collected by Chas. Dury in Hamilton Co. In the O. S. U. Mus., collected by J. S. Hine from Sugar Grove; by W. M. Mills from Chillicothe and from Knox Co.

Sistrurus catenatus catenatus Raf. Brown to grey above, with a series of darker brown blotches edged with black. A yellowish streak through eye to neck. Below blackish, with yellowish shade. Scales 23-25. Length $2 \frac{1}{2}$ feet. Rattles small. Form heavy.

The Massasauga or Prairie Rattler is the smaller of the two species of Rattler in Ohio. It is found in lowland swamps or in grassy meadows. It is sluggish and will not show fight until driven to do so. Its stroke is quick, but not effective beyond a foot.

Formerly the Prairie Rattler was one of the commonest snakes, but now it is undergoing rapid extermination. Its haunts are being invaded by the plough and every year sees many of its strongholts destroyed. Its range in the State is wide, but its distribution is erratic.

Specimens in the U.S. Nat. Mus., recorded by Cope from Columbus, Warren and from Trumbull Co. In O. S. U. Mus., from Urbana, collected by Dr. Kellicott. 
Crotalus horridus L. Above yellowish, with three rows of dark brown spots, irregular in shape and somewhat confluent. A light line from angle of mouth to eye, subtended by a black blotch. Tail darker. Below yellowish to dark grey. Scales 25, sometimes 23. Length 3 feet.

This species is found only in rocky portions of the State. They are now nearly exterminated, but a few remain in certain localities. Thus, among the hills in the Scioto Valley from the line of glacial drift southward, they are met with in small numbers. In the south-eastern portion of the State they are perhaps more frequently taken than elsewhere. On Mouse Island, off Catawba Point, in Lake Erie, there is a small colony that grows smaller every year.

It is the most dangerous of our poisonous reptiles, both because of the venom being very efficient and because of the strength and size of the animal. The fangs are long, reaching even an inch in length. The musculature is powerful.

The food of this reptile consists of small rodents, birds, frogs, etc. It is sluggish in its habits and will not strike unless provoked unduly. Its stroke reaches about two feet.

The writer has seen specimens taken in some of the places mentioned, but there are but few specimens in museums to substantiate its being included here.

One specimen in the zoological collection of the Sandusky High School has a definite record.

\section{Order: TESTUDINATA.}

This order includes the turtles, and concludes the list of Reptiles. No general work on the order is extant and the nomenclature adopted is that given by Jordan ('99), which is that of Dr. Leonard Stejneger of the U. S. N. M.

\section{Family: TrionychidaE.}

* Ampda mutica (Le Sueur). Median line of back depressed. No tubercles. Nostrils not terminal, but rather placed below the end of the snout. Not recorded for Ohio.

Aspidonectes spinifer (Le Sueur). Above flesh color to clay color, covered with black spots. Head and neck striped. Ground color greenish. Feet spotted. Nostrils at tip of snout. Length $\mathrm{I} / 2$ feet. Feet broadly webbed. Body very flat. 
The Soft-shelled turtle is common in every stream of the State. Its flesh is excellent as food. Fishermen frequently catch it on hooks bated with liver or beef. When caught it is very savage and snaps with a will. It may be seen floating at the surface of the river or lake and doubtless derives its food to some extent by this means. Its long proboscis-like appendage bears the nostrils, and this may be pushed above the surface of the water without the body as a whole being conspicuous.

Specimens in the O. S. U. Mus., from Columbus, Sandusky and London, collected by the author.

\section{Family: CHELYdRIDAE.}

Chelydra serpentina ( $\left.L_{\text {. }}\right)$. With median crest, with strong tubercles. Head narrow, pointed, with dark spots. Tail also crested. Plastron small, cross-shaped. Toes 5-4, well webbed. Length 2 feet.

The Snapping-turtle is common over the State. It is, like the preceding, prized as food. It is-never seen out of water save when it lays its eggs in the spring. During the winter it buries itself deep in the mud, but during the warmer days it very probably emerges for a short while or until it becomes cold again.

The Snapper is very savage when caught, and the tenacity with which it grasps a stick or better still a finger is proverbial. Indeed when once the jaws are set down on an object the head may be severed from the body without causing the mouth to open.

Specimens in the Cin. Soc. Nat. His., collected by Dr. Lindahl from Hamilton Co. In the O.S. U. Mus., from Columbus, Sandusky and London, collected by the author.

\section{Family: KINOSTERNIDAE.}

Aromochelys odoratus (Lat.). Carapace long, narrow, high, the highest point being in anterior third of the shell. Carapace somewhat keeled. Above dark, spotted with black. Below yellowish. Length 6 inches.

The Musk-turtle, or Mud-turtle, as it is sometimes called, is very common in the eastern half of the State and in Lake Erie. Westward it becomes abundant. It is never conspicuous. Fishermen very frequently catch it, an operation not especially pleasing to them as it generally means the loss of a hook. They are often seen sunning themselves on rocks and other elevations from the water, but at the slightest disturbance they drop into the water. 
The strong musky odor which gives it its specific name is a ready means for telling it from its brethren.

Specimens in the O. S. U. Mus., from Sandusky, and from Georgesville, collected by the author.

* Pseudemys hieroglyphica (Holb.). Shell flattened, without corrugations. Plastron yellow. Head and neck ornamented with yellow streaks. Upper jaw hooked. Not taken as yet in Ohio. It ranges from New York to Wisconsin and southerly.

\section{Family: EMYdidaE.}

Graptemys geographicus (Le Sueur). Yellowish brown; with greenish and yellow lines forming a reticulation over the carapace. Below yellowish. Carapace denticulate behind, flattened, porterior edges flaring. Toes short. Length $\mathrm{I} / 3$ feet.

An aquatic turtle, leaving the water only to deposit its eggs, Its food is largely clams and gasteropods.

In Ohio it is common in the larger rivers flowing into Lake Erie and the Ohio River.

Specimens in the O. S. U. Mus., from Sandusky, Toledo, Rockport and Cincinnati, collected by W. H. Smith.

Chrysemys marginata (Agassiz). Plates of carapace alternating, never in transverse rows of threes. Above black with a metallic cast, each plate edged with yellowish. Marginal plates with red markings. Plastron yellow, generally blotched with dark brown, Lateral plates sculptured.

This is at once our commonest and most conspicuous turtle, and is too familiar to need any consideration of its habits. Its food consists of mollusks, worms, insects and is indeed omnivorous in its habits. Its eggs are laid in sandy places, a short distance from the water. The young hatch about June 2 oth or later, according to the latitude and temperature.

Specimens in the O.S. U. Mus., from Columbus, and from Newton Falls, Vinton and Sandusky by the author.

* Chrysemys picta (Hermann). As above, but dorsal plates arranged in sets of three, not alternating.

This turtle is given by Smith ('82) as found in eastern Ohio, and other writers follow him. However, careful collecting in eastern Ohio has failed to reveal its presence. If it occurs it does so sparingly.

Clemmys guttatus (Sch.) Carapace black, covered with circular orange spots about one-fourth inch in diameter. Plastron yellow, heavily blotched with black. Length 5 inches. 
This is a gaudy creature and is noticeable in its environment. It frequents still ponds and streams or marshy places, In Buckeye Lake, where it is to be found sparingly, it is seen sometimes in the interior of one of the Sphagnum bogs away from water. It is also seen among several individuals of $C$. marginata sitting on a $\log$ in the sunshine. They are shy and are in the water at once when disturbed. They feed on mollusks, frogs, tad-poles, etc., while insects enter largely into their diet.

While not rare in Ohio they are by no means common. However, they doubtless occur in small numbers in all parts.

Specimens in the O. S. U. Mus., collected by the author from the Licking Reservoir, Castalia and Columbus.

Emynoidea blandingi (Holbr.). Carapace black, covered with small, yellow spots. Plastron with large, black blotches. Yellow spots on head. Length 8 inches.

Found in the larger streams flowing into Lake Erie and the Ohio River. It is a large species, but inconspicuous, and its habits are not well known. The species is nowhere abundant, even in its more normal habitat. It has been observed by the writer in the sand on Cedar Point, Sandusky, early in July, apparently ovipositing. On approaching it it draws in head and legs and closes its shell and no amount of thumping will cause it to open the hinged plastron.

Specimens in the O.S. U. Mus., from Columbus and Sandusky.

Terrapene carolina (L.). Carapace short, high and thrown into many rugosities. Above yellow, with black markings. Plastron hinged in front and behind, capable of closing the shell tight. Length 6 inches. Variable.

This is the common Box-turtle. While nowhere common in Ohio, it is met with now and then in every portion of the State. It is strictly terrestrial. Their food consists of insects mainly, but unlike any other turtle of the State, is a vegetarian to some extent, eating fungi, roots, potatoes, etc. They are long-lived, and stories are commonly heard of their extreme longevity, based on a specimen that had been discovered bearing an inscription, carved on its shell, which had been made years before.

Specimens in the Cin. Soc. Nat. His., from Hamilton Co., collected by Dr. Lindahl. In the O. S. U. Mus., collected by Prof. J. H. Schaffner from Sugar Grove ; from Georgesville, by Mr. Coberly, and from Vinton by the author. 


\section{COLLECTING AND PRESERVING.}

Inasmuch as it is very desirable that further collecting of the reptiles and batrachians of the State be made, directions are given for capturing and preserving these forms. For the salamanders, which are slippery and very difficult to hold, a noose of fine wire is a splendid instrument; the noose can be slipped over the head of the specimen without disturbing it, and a quick jerk will close the noose and the specimen can be dropped into the collecting box. Frogs are difficult to catch and resort is often made to the use of a small-bored gun, loaded with dust shot. A thirty-two calibre collecting gun with shot cartridges is an efficient instrument. The writer has never had any success with the use of a fish-hook, covered with a red cloth which is suspended over a frog by means of a pole and line and the hook fastened by a sudden jerk into the lower jaw of the specimen, a method recommended by some.

For lizards, a gun somewhat as described above is almost necessary as their motions are very quick. Snakes may be caught by grasping with the fingers or with long forceps, just back of the head. Gloves may be worn to advantage with the larger species. This is, however, not a method that recommends itself for the capture of our venomous reptiles, as mistakes of a very serious nature may arise. For the larger snakes and the venomous ones, forceps may be used or a forked stick may be pushed over the head of the specimen-the specimen and fork being pushed into the ground. To kill snakes and turtles, there is but one practical method, as far as the author's experience goes, and that is to soak a piece of cotton with ether or chloroform and push it by means of forceps into the mouth. The specimen may then be left until dead, which time varies with the kind of specimen from a few minutes, as with some snakes, to a day, as with the larger turtles. A large cyanide bottle, as used by entomologists, serves to kill salamanders and frogs. Otherwise an air-tight box can be used, in which the specimens can be placed and into which cotton, saturated with chloroform, can be dropped.

Specimens may be best preserved in a 5 per cent. solution of formalin.* Formalin is the anglicized form of the German formol, which is a more correct term, chemically speaking. It is a 40 per cent. solution of the gas formaldehyde, $\mathrm{CH}_{2} \mathrm{O}$, in water.

\footnotetext{
* Formalin or formol or formaldehyde, as it is variously called may be bought on the market at a small expense. A pound bottle, which costs about 40 cents will preserve a large number of specimens.
} 


\section{GLOSSARY.}

Anteorbital Plates. Plates bounding the eyes in front.

Arboreal. Living in trees.

Canthus Rostralis. . Tubercle at angle of jaw.

Carapace. The upper shell of a turtle.

Carinate. Keeled. Said of a structure when a ridge runs along the median line.

Costal Folds. The furrows on the sides of a salamander which mark the position of the ribs.

Fangs. The enlarged front teeth of a venomous snake which are used as hypodermic needles for the injecting of venom.

Fauna. The animal life of a region, taken as a whole.

Gastrosteges. The scales. on the belly of a snake in front of the tail.

Larva. The young or immature form of an animal before reaching the full-grown or adult stage.

Lateral. Pertaining to the sides of an animal.

Occipital. The hinder portion of the head, immediately in front of the neck.

Oviparous. Producing eggs that are hatched outside the parent's body.

Ovoviviparous. Producing eggs that are developed within the parent's body.

Palustrine. Inhabiting swamps.

Plastron. "The lower shell of a turtle.

Postorbital. Plates lying behind the eyes, bounding them posteriorly.

Punctate. Dotted.

Scales. The number of vertical rows of scales running across the body from the gastrosteges.

Rostrum. The beak-like structure at the tip of the snout in some snakes.

Striate. Streaked.

Ventral. Pertaining to the lower surface of an animal.

Viviparous. Bringing forth young alive. 


\section{IN DEX.}

Acris................... 118

Amblystoma.............. Io7

Amphibamus.............. I05

Amyda ................ I38

Ancistrodon............. I 137

Anisodexis ............... I06

Aromochelys ............... I39

Aspidonectes ............. I 38

Bascanion................ 128

Black-snake. . . . . . . . . . I 28

Blow-viper .............. I 26

Blue-racer............... I 28

Blue-tailed Skink........... I25

Box-turtle............... I4I

Brachydectes............. I05

Bufo.................. Ir

Bull-frog............... I2I

Bull-snake............... I 29

Carphophiops............. I 25

Cercariomorphus ............ I06

Chelydra................. I39

Chorophilus.............. II8

Chrysemys.............. 140

Clemmys................. 140

Clonoplus............... I28

Cnemidophorus ............ r24

Cocytinus ............... I05

Colosteus ............... Io6

Coluber................. 128

Common Water-snake........ I3I

Copper-head.............. I37

Cricket-frog ............. Ir8

Crotalus................. r38

Cryptobranchus............ ro7

Desmognathus ............ II

Diadophis............... I 26

Diemyctylus............. I 6

Emynoidea............... I4I

Eumeces................ I 25

Eurythorax.............. I05

Fox-snake.............. 129

Garter-snake .............. r34

Glass-snake .............. r 24

Graptemys.............. I40

Gyrinophilus............ II2

Hell-bender ............. ro7

Hemidactylum ............. r ro

Heterodon.................. 126

Hyla ..................... Ix

Hyphasma ............... 106
Icthyacanthus ........... I05

Isodectes................ I 23

Keraterpeton............. 106

Leptophractus............ Io5

Liolepisma .............. I 124

Liopeltis................ I27

Little Tree-toad............. I I9

Massasauga.............. I37

Milk-snake.............. I30

Molgophis............... ro6

Mud-puppy.............. Io6

Mud-turtle .............. I39

Musk-turtle............... I39

Natrix ............... I3I

Necturus................. ro6

Newt.................. II6

Oestocephalus ............. I06

Osceola .................. 130

Pelion................. 105

Phlegethontia ............. I06

Pilot Black-snake. . . . . . . . . . . I 29

Pine-snake ............... I 129

Pine-tree Lizard ............ 1 23

Plethodon................ II I

Pituophis................. I 29

Pleuroptyx............. ... ro6

Prairie Rattler............. I37

Pseudemys............... I40

Ptyonius................ I06

Rana.................... I II

Red-bellied Water snake...... I3I

Sauropleura .............. Io6

Sceloporous .............. I 23

Sistrurus................ I 37

Snapping-turtle...... ..... I39

Soft-shelled Turtle.......... I39

Southern Water-snake ........ I30

Spelerpes................ II4

Storeria................ I33

Swamp-frog ............ I2I

Terrapene............... I4I

Thyrsidium.. $\quad \ldots \ldots \ldots \ldots \ldots$ ro6

Toad ................ II7

Tree-toad................. r20

Tuditanus................ I05

Wood-frog .............. 122

Virginia................ I33 
11. $B-13$

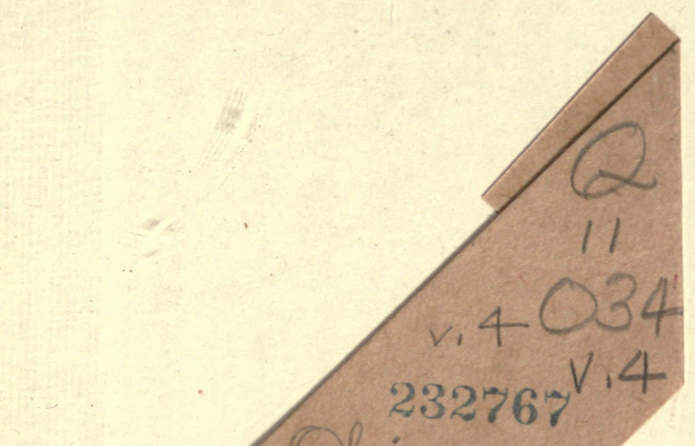

(Chio 


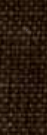

